\title{
Thermal Management of Electric Vehicle Batteries Using Heat Pipe and Phase Change Materials
}

\author{
Muhammad Amin ${ }^{1,2}$, Bambang Ariantara ${ }^{1,3}$, Nandy Putra ${ }^{1, *}$, Adjie Fahrizal Sandi ${ }^{1}$, and Nasruddin A. Abdullah ${ }^{1,2}$ \\ ${ }^{1}$ Applied Heat Transfer Research Group, Department of Mechanical, Faculty of Engineering, Universitas Indonesia, \\ Kampus Baru- Depok, Jawa Barat, 16424, Indonesia \\ ${ }^{2}$ Department of Mechanical Engineering, Faculty of Engineering, Universitas Samudra, Kampus Meurandeh, Langsa \\ Lama-Kota Langsa, 24416, Indonesia \\ ${ }^{3}$ Department of Mechanical Engineering, Faculty of Engineering, Universitas Pasundan, Bandung, 40116, Indonesia
}

\begin{abstract}
The performance of an electric vehicle depends on the battery used. While, in the operation of an electric vehicle, batteries experience a quick heating especially at the beginning of charging and could cause a fire. Therefore, the solution could be proposed is by employing heat pipe and Phase Change Material (PCM) for cooling of battery. The heat pipe serves to transfer the battery's heat energy. In other hands, PCM functions as a heat sink when the battery runs, so its performance will stable and extend the lifespan. This study aimed to evaluate the performance of electric vehicle batteries at a temperature of 50 ${ }^{\circ} \mathrm{C}$ using the combination of heat pipe and PCM. The ' $\mathrm{L}$ ' type of heat pipe and beeswax PCM were assembled as cooling device. In addition, a battery simulator was employed as a test instrument by varying the heat load of $20,30,40$, and $50 \mathrm{~W}$. The experiments were successfully conducted, and the results showed that the addition of heat pipe and PCM could keep the surface temperature of battery below $50^{\circ} \mathrm{C}$, at heat load of $20-50 \mathrm{~W}$. Heat pipe and PCM for battery's cooling system, can reduce the battery surface temperature significantly and can be proposed as an alternative system for cooling battery.
\end{abstract}

\section{Introduction}

The battery is a device for storing energy and releasing it in the form of electrical power. It plays an important role in the operation of electric cars. As one of the major energy sources, it is required to perform, at least, as well as fossil fuels. This demands a significant development, especially on the energy distribution and battery's lifespan within a certain period. Moreover, its performance depends on the temperature as well. Generally, the permitted temperature in the thermal management application is below $50{ }^{\circ} \mathrm{C}$.

Batteries consist of electrochemical cells capable of converting chemical into electrical energies and vice versa. The most often utilized batteries, which possess high power, are nickel metal hydride (Ni-MH) and lithium-ion (Li-ion). Both have advantages and disadvantages. The drawback of Ni-MH types is very expensive, bulky and weighty [1]. On the other hands, Li-ion batteries offer better price, size, and weight than $\mathrm{Ni}-\mathrm{MH}$ [2]. Consequently, the usage of Li-ion series is often found in electric cars [3].

Mostly, there are two main problems in the case of temperature [4]. First, high temperature during charging and discharging causes it exceeds the permitted level and reduces the battery's performance. Second, the uneven distribution of temperature on the battery leads to localized damage.

To overcome the thermal management could be achieved through various methods such as, relying on natural convection (passively) and operating additional media as heating/cooling (actively). Fan, heat pipe, thermoelectric and Phase Change Material (PCM) might be operated as active and passive method $[5,6]$. Fan and thermoelectric can be used as battery cooling system but PCM and heat pipe have better performance to reduce battery temperature. Heat pipe and PCM have advantages such as have high efficiency, easy to use and integrate, can reduce more battery temperature equally, and can be used more than 20 years [6]. Therefore, in this study, we observed the advantage of application of heat pipe and PCM on thermal battery management system of electric vehicles.

To obtain effective results, the selection of the appropriate PCM type is a major factor, as either a heater or a coolant. One of the PCM selection criteria is the melting point, which must be within the desired operating temperature range [4]. Based on existing reference, it is approximately $40-60{ }^{\circ} \mathrm{C}$.

Some researchers who used PCM on battery management systems, such as Al-Hallaj and Selman [7] stated that PCM could reduce battery temperatures that

\footnotetext{
Corresponding author: nandyputra@eng.ui.ac.id
} 
dropped instantly, for instance, Li-ion batteries used in space satellites. Since satellites move around the earth, it causes a sudden drop in temperature that affects battery's performance. They also mentioned that cooling the battery using a PCM is more beneficial than conventional natural cooling. Sabbah et al. [5] performed numerical and experimental tests and found that PCM was better than forced air-cooling, where at the time the battery runs, PCM preserve battery's temperature below $55{ }^{\circ} \mathrm{C}$. Mills and Al-Hallaj [8] simulated batteries' usage in laptops, where as long as the batteries functioned, PCM also kept it less than 55 ${ }^{\circ} \mathrm{C}$. Samimi et al. [9] applied a PCM carbon fibre composite to cool down the Li-ion battery. In their study, the effect of PCM carbon fibre composite could be maintained at a temperature of $52.3{ }^{\circ} \mathrm{C}$. In addition, Wang et al. [10], have performed research on the thermal battery management system of electric vehicles employing heat pipe and PCM, where oscillating heat pipe (OHP) added to PCM is managed to the same purpose. Accordingly, it was found that this combination could reduce the temperature below $50^{\circ} \mathrm{C}$.

The heat pipe is a closed tube consisting of three parts, namely evaporator, adiabatic part, and condenser [11]. In this study, we combined the use of heat pipe and PCM to facilitate the improving and more durable battery's performances.

This study aimed to maintain the performance of electric vehicle batteries at a temperature of $50{ }^{\circ} \mathrm{C}$ by utilizing heat pipe and PCM. The heat pipe serves to transfer heat energy in the batteries and it will be decreased subsequently. Whereas PCM acts as a heat sink to preserve the batteries' performance and prolonged the batteries' usage.

\section{Methodology}

\subsection{Research Designs}

In this study, the simulated battery was a lithium-ion type, and the working temperature is kept below $50{ }^{\circ} \mathrm{C}$ [12]. When tested, two aluminium simulators were manufactured with size $48 \times 82 \times 138 \mathrm{~mm}$ as lithiumion batteries. Within each simulator, a heater is installed precisely in the middle of the simulator, $6.3 \mathrm{~mm}$ diameter, $110 \mathrm{~mm}$ in length, and a maximum power of $240 \mathrm{~W}$.

A shaped "L" heat pipe with fins [13] and beeswax PCM with a melting point of $62.28{ }^{\circ} \mathrm{C}$ and specific latent heat of $141.49 \mathrm{~kJ} / \mathrm{kg}$ [14] were employed in this experiment. Furthermore, the heat pipe and PCM were mounted on copper plates, which have channels for placing the two-main apparatus. In details, PCM was inserted into a copper plate holder with a mass of 15 grams. To prevent leakage of PCM, gaskets were joined up. All of the equipment is shown in Fig. 1.
The battery simulator test device using heat pipe and PCM is set in an acrylic air duct. A fan was installed in order to cooling down the condenser of heat pipe.

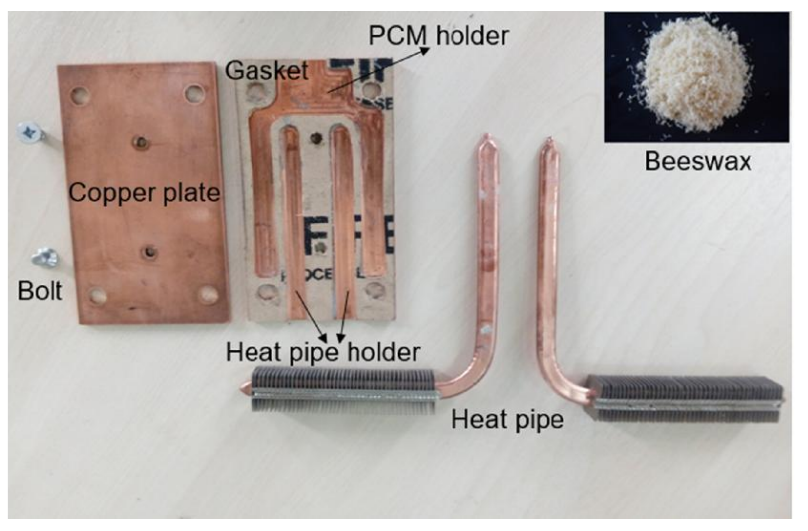

Fig. 1. Equipment managed in this research: heat pipe, PCM, and copper plate.

\subsection{Method}

The main parameter tested was temperature with the variation of heat load: 20,30, 40 and $50 \mathrm{~W}$. The k-type thermocouples with $0.3 \mathrm{~mm}$ in diameter, were mounted on the assembled prototypes. Correspondingly, they were positioned on the surface of each battery.

Afterward, the prototype is inserted into the air duct equipped with a fan, which works to flow the cold air into the condenser. The installed thermocouples are connected to two NI DAQ 9214 modules with NI CDAQ 9214 type chassis. The Yokogawa power meter is also fitted to measure power, voltage, and electric current. Then, all data obtained from reading of NI DAQ module were recorded and stored on a computer device, then will be processed into a graph. An AC voltage regulator was used to obtain a stable voltage. Additionally, the schematic thermal battery management system is shown in Fig. 2.

The test was started by turning on the fan on the air duct at a constant speed of $2.4 \mathrm{~m} / \mathrm{s}$ together with temperature and power meter data acquisition systems. The voltage was set at $20 \mathrm{~W}$, which causes the increase of the prototype temperature. It should be observed on the computer monitor screen. When the temperature did not change anymore within 10 minutes, this condition was considered as steady state condition. Next, the power of the heater was varied at 30,40 , and $50 \mathrm{~W}$.

The test was conducted in three parts, firstly, without using heat pipe and PCM, second, using heat pipe, and the third, using heat pipe and PCM. Data from these three treatments were analysed and compared. Air temperature should be ascertained equally for all actions in order to obtain data that are more accurate. 


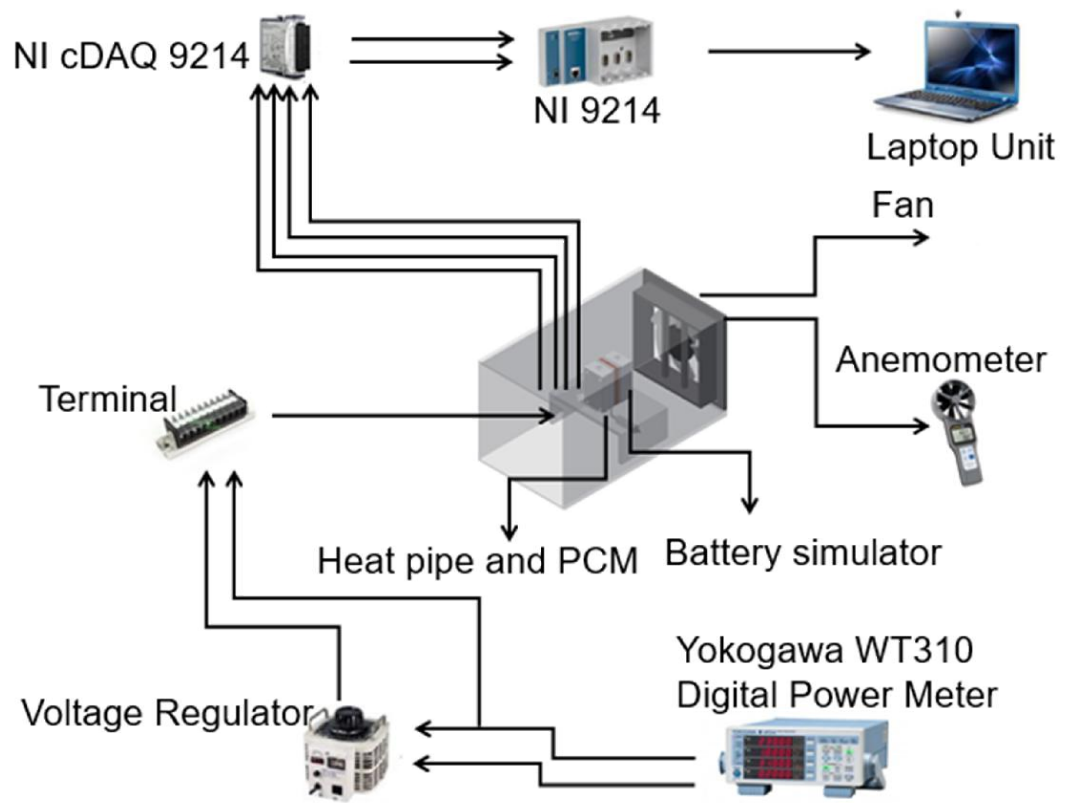

Fig. 2. Schematic thermal battery management system

\section{Results and Discussions}

\subsection{Temperature profile on the surface of the electric battery}

The PCM application on thermal management system based on heat pipe has been successfully performed. Figures 3 and 4 illustrated the battery's surface temperature profile in three treatments, namely without heat pipe and PCM, with only a heat pipe, and with combination of heat pipe and PCM, with the condition of the heat loads were 20, 30, 40 and $50 \mathrm{~W}$.

The temperature on the battery's surface showed the enhancement, proportioned with the increasing of heat load, and it displayed as steady at a certain time. At the applied of the heat load maximum of $50 \mathrm{~W}$, the condition of battery's surface temperature is adjacent to the highest permitted temperature of $50{ }^{\circ} \mathrm{C}$. On the other hands, ambient temperatures for each test emerged fluctuate between $26-28{ }^{\circ} \mathrm{C}$. This shape appeared as the influence of room air condition. Occasionally, this test has successfully conditioned the steady temperature profile for each battery's surface.

The effect of using only heat pipe and heat pipe + PCM are shorten the required time to reach the steady temperature of battery's surface, \pm 1.5 hours. Compared by the system without using heat pipe and PCM, it took more than 3 hours due to the cooling process only obtain from natural convection.

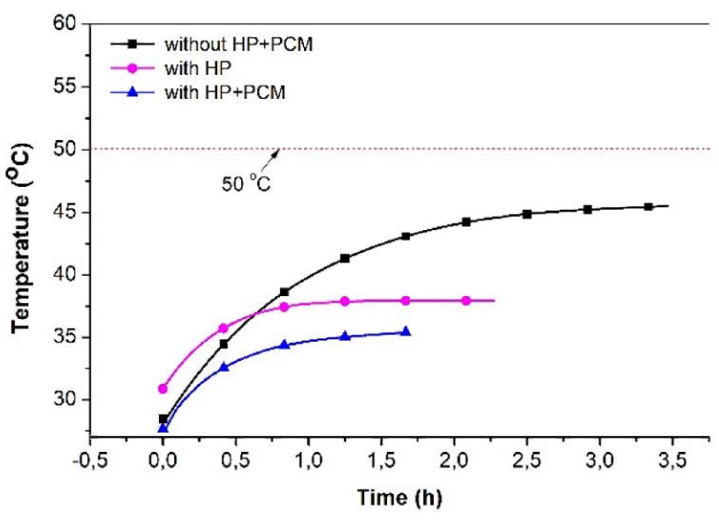

(a) $20 \mathrm{~W}$

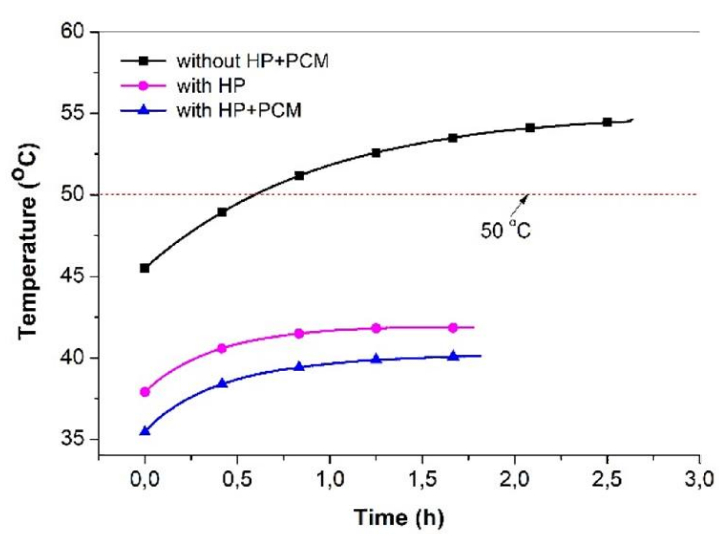

(b) $30 \mathrm{~W}$

Fig. 3. Comparison of temperature profile at heat loads $20 \mathrm{~W}$ and $30 \mathrm{~W}$ 


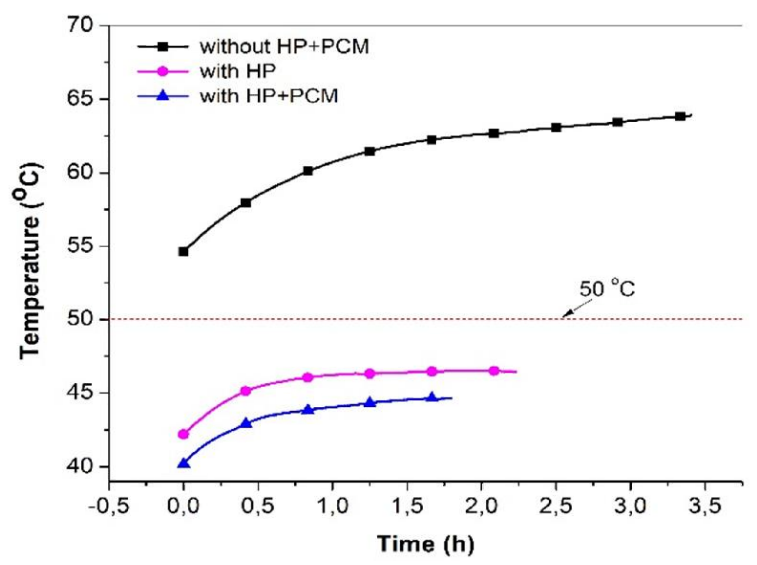

(c) $40 \mathrm{~W}$

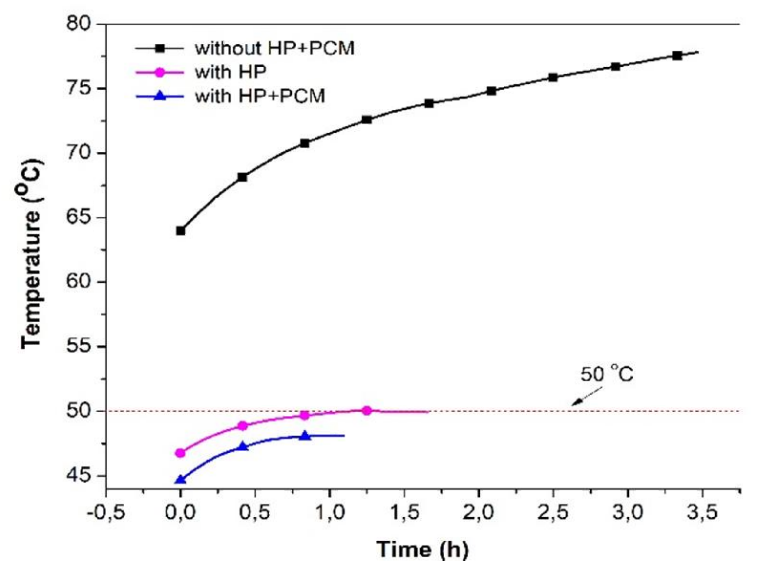

(d) $50 \mathrm{~W}$

Fig. 4. Comparison of temperature profile at heat loads $40 \mathrm{~W}$ and $50 \mathrm{~W}$

Overall, the effect of the heat pipe and heat pipe + PCM for cooling system of battery will decrease the temperature on the battery's surface significantly. If only using the heat pipe, it occurs due to the heat absorption by the evaporator. Afterward, it was sprung into the condenser and released it into the air. Meanwhile, if heat pipe combined with PCM, the temperature also decreases, and its result is improved than by applying the heat pipe only. Accordingly, this reduction has occurred, where the heat was absorbed by the PCM first, therefore, the heat pipe's work is lighter.

The degree of the surface temperature decreases due to the presence of heat pipe and heat pipe + PCM is shown in Fig. 5. The temperature decreased from 45.5 ${ }^{\circ} \mathrm{C}$ to $37.9^{\circ} \mathrm{C}$ or decreased by $7.6{ }^{\circ} \mathrm{C}$, when heat pipe was applied at 20 watts. Compared by using heat pipe + $\mathrm{PCM}$ at the same heat load, the temperature decreased lower by $10.1{ }^{\circ} \mathrm{C}$, from $45.5^{\circ} \mathrm{C}$ to $35.4{ }^{\circ} \mathrm{C}$. Likewise, for 30,40 , and 50 watts of heat loads, it appears the same result performance. Furthermore, by adding heat pipe + PCM displayed the similar tendencies. It lowered the battery's surface temperature by $1.5-2{ }^{\circ} \mathrm{C}$ compared to applying heat pipe only. Similar to other experiments $[8,10]$, battery temperature could be maintained under $50{ }^{\circ} \mathrm{C}$ on all heat load conditions.

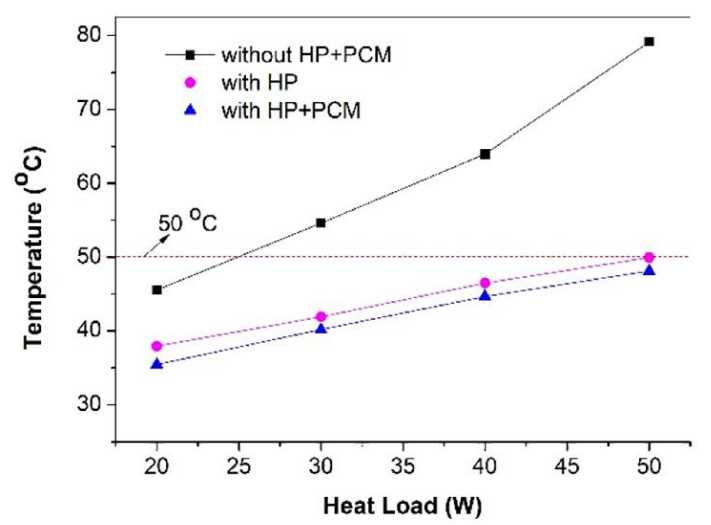

Fig. 5. Battery surface temperature in steady state condition.

\section{Conclusions}

Thermal management system testing of battery by using the heat pipe and PCM has been conducted. The temperature of batteries electric vehicle can be maintained below $50{ }^{\circ} \mathrm{C}$. In application of heat pipe only, at $20 \mathrm{~W}$ heat loads, it reduced the surface temperature from $45.5{ }^{\circ} \mathrm{C}$ to $37.9{ }^{\circ} \mathrm{C}$, while at $50 \mathrm{~W}$ it decreased from $79.1{ }^{\circ} \mathrm{C}$ to $49.9^{\circ} \mathrm{C}$. Compare with heat pipe + PCM application, at $20 \mathrm{~W}$, it lowered the surface temperature from $45.5^{\circ} \mathrm{C}$ to $35.4^{\circ} \mathrm{C}$ and $79.9^{\circ} \mathrm{C}$ to 48.1 ${ }^{\circ} \mathrm{C}$ at $50 \mathrm{~W}$. This combination of heat pipe and beeswax PCM can be used as alternative for cooling battery application.

The authors express gratitude to DRPM Universitas Indonesia for funding this research through the "PITTA 2018" scheme.

\section{References}

1. M. Kromer, "Electric powertrains: opportunities and challenges in the US light-duty vehicle fleet," (2007)

2 M. Broussely, J. P. Planchat, G. Rigobert, D. Virey, and G. Sarre, "Lithium-ion batteries for electric vehicles: performances of 100 Ah cells," $J$. Power Sources, vol. 68, no. 1, pp. 8-12, Sep. (1997)

3. M. WADA, "Research and development of electric vehicles for clean transportation," J. Environ. Sci., vol. 21, no. 6, pp. 745-749, Jan. (2009)

4. Z. Rao and S. Wang, "A review of power battery thermal energy management," Renew. Sustain. Energy Rev., vol. 15, no. 9, pp. 4554-4571, Dec. (2011)

5. R. Sabbah, R. Kizilel, J. R. Selman, and S. AlHallaj, "Active (air-cooled) vs. passive (phase change material) thermal management of high power lithium-ion packs: Limitation of temperature rise and uniformity of temperature distribution," J. Power Sources, vol. 182, no. 2, pp. 630-638, Aug. (2008) 
6. M. R. Cosley and M. P. Garcia, "Battery thermal management system," in 2004 10th International Workshop on Computational Electronics (IEEE Cat. No.04EX915), pp. 38-45

7. S. Al Hallaj and J. R. Selman, "A Novel Thermal Management System for Electric Vehicle Batteries Using Phase-Change Material," J. Electrochem. Soc., vol. 147, no. 9, p. 3231, Sep. (2000)

8. A. Mills and S. Al-Hallaj, "Simulation of passive thermal management system for lithium-ion battery packs," J. Power Sources, vol. 141, no. 2, pp. 307-315, Mar. (2005)

9. F. Samimi, A. Babapoor, M. Azizi, and G. Karimi, "Thermal management analysis of a Li-ion battery cell using phase change material loaded with carbon fibers," Energy, vol. 96, pp. 355-371, Feb. (2016)

10. Q. Wang, Z. Rao, Y. Huo, and S. Wang, "Thermal performance of phase change material/oscillating heat pipe-based battery thermal management system," Int. J. Therm. Sci., vol. 102, pp. 9-16, Apr. (2016)

11. S. Muhammaddiyah, A. Winarta, and N. Putra, "Experimental Study of Heat Pipe Heat Exchanger Multi Fin for Energy Efficiency Effort in Operating Room Air System," Int. J. Technol., vol. 9, no. 2, p. 422, Apr. (2018)

12. J. Zhao, Z. Rao, C. Liu, and Y. Li, "Experimental investigation on thermal performance of phase change material coupled with closed-loop oscillating heat pipe (PCM/CLOHP) used in thermal management," Appl. Therm. Eng., vol. 93, pp. 90-100, Jan. (2016)

13. N. Putra and B. Ariantara, "Electric motor thermal management system using L-shaped flat heat pipes," Appl. Therm. Eng., vol. 126, pp. 11561163, Nov. (2017)

14. M. Amin, N. Putra, E. A. Kosasih, E. Prawiro, R. A. Luanto, and T. M. I. Mahlia, "Thermal properties of beeswax/graphene phase change material as energy storage for building applications," Appl. Therm. Eng., vol. 112, pp. 273-280, Feb. (2017) 